\title{
A New Serovar in the Grippotyphosa Serogroup Comprising Leptospiral Isolates from Different Regions
}

\author{
J. L. HERRMANN,${ }^{1}$ P. BAKOSS,${ }^{2}$ H. KORVER, ${ }^{3}$ A. A. BULU, ${ }^{4}$ E. BELLENGER, ${ }^{1}$ W. J. TERPSTRA, ${ }^{3}$ \\ I. SAINT GIRONS, ${ }^{1}$ AND G. BARANTON ${ }^{1 *}$ \\ Unité de Bactériologie Moléculaire et Médicale, Institut Pasteur, 75724 Paris Cédex 15, France ${ }^{1}$; Department of \\ Epidemiology, Medical Faculty of Komensky-University, 81108 Bratislava, Slovakia ${ }^{2}$; N. H. Swellengrebel \\ Laboratory of Tropical Hygiene, The Royal Tropical Institute, Amsterdam, The Netherlands ${ }^{3}$; \\ and Veteriner Kontrol ve Arastirma Enstitusu, 06020 Etlik-Ankara, Turkey ${ }^{4}$
}

\begin{abstract}
Pulsed-field gel electrophoresis (PFGE) studies performed with leptospiral isolates led us to suspect the existence of a new serovar in the Grippotyphosa serogroup. The results obtained with reference serological techniques used in leptospiral identification, including cross-agglutination absorption and monoclonal antibody techniques, confirmed the existence of a new serovar exemplified by strain Dadas I. Four other isolates from different regions of the world were submitted for identification by PFGE and produced NotI restriction patterns similar to that of strain Dadas I. Our data demonstrate the power of PFGE for identifying leptospiral isolates. The name dadas is proposed for the new serovar.
\end{abstract}

Pathogenic leptospires are spirochetes that were first isolated and identified by Inada et al. in 1915 (9). These microorganisms are responsible for a zooanthroponosis of worldwide distribution, the symptoms of which were classically described by Weil in $1886(20)$. The main advance in our knowledge of spirochete phylogeny came from the results of 16S RNA sequence determinations. Spirochetes represent one of the oldest bacterial phyla within the eubacteria (21). The phylogenetic separation of these organisms is based on specific morphological characteristics, including a helical form and the presence of an internal locomotor organelle (2). The family Leptospiraceae within the spirochetes (8) contains two genera, Leptospira and Leptonema (17). The genus Leptospira can be differentiated into two nomenspecies, the nonpathogenic taxon Leptospira biflexa sensu lato and the pathogenic taxon Leptospira interrogans sensu lato $(10)$. The $\mathrm{G}+\mathrm{C}$ contents of the DNAs of these organisms range from 36 to $39 \%$ mol\% (17, 19). On the basis of DNA-DNA hybridization results, 10 genomic species have been identified within the two nomenspecies (pathogenic and nonpathogenic) $(18,22)$.

Early in this century, leptospires were classified by using serological criteria. By using the agglutination-lysis reaction developed by Martin and Pettit (16), it was possible to discriminate Leptospira strains having different antigenic properties. Within the nomenspecies $L$. interrogans, more than 200 serovars can be distinguished; these serovars are grouped into 23 serogroups (13). The nomenspecies $L$. biflexa contains 65 serovars divided into 38 serogroups (13). The grouping of serovars into serogroups is based on antigenic similarities between serovars and is used for practical reasons.

The serovar is considered as the basic taxon. When the microscopic agglutination and cross-agglutinin absorption tests are used (10), two serovars are considered to be differentiated if, after cross-absorption with adequate amounts of heterologous antigen, $10 \%$ or more of the homologous titer regularly remains in at least one of the two antisera (5). Serological identification of Leptospira strains by these reference proce-

\footnotetext{
* Corresponding author. Mailing address: Unité de Bactériologie Moléculaire et Médicale, Institut Pasteur, 28 rue du Docteur Roux, 75724 Paris Cedex 15, France. Phone: 331456883 37. Fax: 3314061 3001. Electronic mail address: gbaran@pasteur.fr.
}

dures is long and time consuming. To circumvent such difficulties, different workers have chosen to prepare mouse monoclonal antibodies (MAbs) directed against specific epitopes of reference strains $(14,15,19)$. This technique, which depends on the use of a collection of carefully chosen MAbs, gives results which correlate well with cross-absorption results. Another strategy is to use a restriction endonuclease and pulsedfield gel electrophoresis (PFGE) $(6,7)$. This technique permits identification of any serovar which possesses a specific and clear banding pattern when its DNA is cut with restriction endonuclease NotI; the patterns are called large restriction fragment patterns (LRFP). Clinical isolates can be identified by comparison with a data bank consisting of the LRFPs obtained with numerous serovars.

In the course of a study of new isolates obtained from mammals (7), one strain belonging to the Grippotyphosa serogroup, Dadas I, was found to produce a specific DNA restriction pattern with endonuclease NotI (7). Strain Dadas I, which was isolated from a bull in Turkey, was studied further. In this paper, we describe serovar identification of strain Dadas I by the cross-absorption procedure, the MAb technique, and PFGE. Four other mammal isolates belonging to the Grippotyphosa serogroup (Kornilov, Bernkopf, Kizilchaman, and Karakabay) produced LRFPs and MAb patterns similar to those of strain Dadas I.

All strains were cultivated in EMJH or Korthof's media (4, $11,12)$. A DNA restriction analysis by PFGE was performed as previously described $(1,7)$. Antisera for cross-absorption were produced in paired rabbits by using the eight reference serovars in serogroup Grippotyphosa and strain Dadas I $(3,5,12)$. Strain Dadas I was tested against the serogroup Grippotyphosa reference antisera, while the serogroup Grippotyphosa reference serovars were tested against antiserum to strain Dadas I by the microagglutination test $(12,16)$. Thirteen MAbs, which were produced as previously described $(14,19)$, were used to discriminate among reference serovars of serogroup Grippotyphosa and to compare these taxa with strain Dadas I.

According to the cross-agglutination test results, strain Dadas I belongs to the Grippotyphosa serogroup. On the basis of the results of reference agglutination tests after crossabsorption tests (Table 1), strain Dadas I was found to be closely related to serovars grippotyphosa, valbuzzi, vanderhoeni, ratnapura, and huanuco. However, when we used 
TABLE 1. Cross-adsorption results with Leptospira strains belonging to the Grippotyphosa serogroup and strain Dadas I

\begin{tabular}{|c|c|c|c|c|}
\hline $\begin{array}{l}\text { Immunserum } \\
\text { against strain }{ }^{a} \text { : }\end{array}$ & Serovar & $\begin{array}{l}\text { Absorbed } \\
\text { with: }\end{array}$ & $\begin{array}{c}\text { Microaggluti- } \\
\text { nation test } \\
\text { with strain: }\end{array}$ & $\begin{array}{l}\text { Agglutina- } \\
\text { tion titer } \\
\left(10^{3}\right)^{b}\end{array}$ \\
\hline \multirow[t]{2}{*}{ Moskva V } & grippotyphosa & 0 & Dadas I & 25 \\
\hline & & Dadas I & Moskva V & $<0.2$ \\
\hline \multirow[t]{2}{*}{ Valbuzzi } & valbuzzi & 0 & Dadas I & 25 \\
\hline & & Dadas I & Valbuzzi & $<0.1$ \\
\hline \multirow[t]{2}{*}{ CZ 188} & canalzonae & 0 & Dadas I & 25 \\
\hline & & Dadas I & CZ 188 & 3 \\
\hline \multirow[t]{2}{*}{ Kipod 179} & vanderhoedeni & 0 & Dadas I & 12 \\
\hline & & Dadas I & Kipod 179 & 0.2 \\
\hline \multirow[t]{2}{*}{ Wumalasena } & ratnapura & 0 & Dadas I & 25 \\
\hline & & Dadas I & Wumalasena & 0.1 \\
\hline \multirow[t]{2}{*}{ RM2 } & muelleri & 0 & Dadas I & 25 \\
\hline & & Dadas I & RM 2 & 3 \\
\hline \multirow[t]{2}{*}{1880} & liangguang & 0 & Dadas I & 25 \\
\hline & & Dadas I & 1880 & 12 \\
\hline \multirow[t]{2}{*}{ M4 } & huanuco ${ }^{c}$ & 0 & Dadas I & $<0.1$ \\
\hline & & ${\text { Dadas } \mathrm{I}^{d}}$ & 0 & 0 \\
\hline \multirow[t]{2}{*}{ Dadas I } & dadas & 0 & Moskva V & 25 \\
\hline & & Moskva V & Dadas I & 3 \\
\hline \multirow[t]{2}{*}{ Dadas I } & dadas & 0 & Valbuzzi & 25 \\
\hline & & Valbuzzi & Dadas I & 6 \\
\hline \multirow[t]{2}{*}{ Dadas I } & dadas & 0 & CZ 188 & 25 \\
\hline & & CZ 188 & Dadas I & 12 \\
\hline \multirow[t]{2}{*}{ Dadas I } & dadas & 0 & Kipod 179 & 1 \\
\hline & & Kipod 179 & Dadas I & 12 \\
\hline \multirow[t]{2}{*}{ Dadas I } & dadas & 0 & Wumalasena & 12 \\
\hline & & Wumalasena & Dadas I & 3 \\
\hline \multirow[t]{2}{*}{ Dadas I } & dadas & 0 & RM 2 & 12 \\
\hline & & RM 2 & Dadas I & 6 \\
\hline \multirow[t]{2}{*}{ Dadas I } & dadas & 0 & 1880 & 25 \\
\hline & & 1880 & Dadas I & 25 \\
\hline \multirow[t]{2}{*}{ Dadas I } & dadas & 0 & M4 & 6 \\
\hline & & M4 & Dadas I & 6 \\
\hline
\end{tabular}

${ }^{a}$ The homologous titers were $12 \times 10^{3}$ to $25 \times 10^{3}$. Each serological reaction with a heterologous antigen after absorption was negative (titer, $<0.1 \times 10^{3}$ ).

${ }^{b}$ Antibody titers are expressed by the reciprocal of the serum dilution.

c This serovar provisionally belongs to serogroup Grippotyphosa.

${ }^{d}$ Absorption experiment not performed.

immune serum against Dadas I, none of the reference strains used removed antibodies that reacted with the homologous strains (Table 1). This means that strain Dadas I has a main antigen not present in any of the other Grippotyphosa sero-

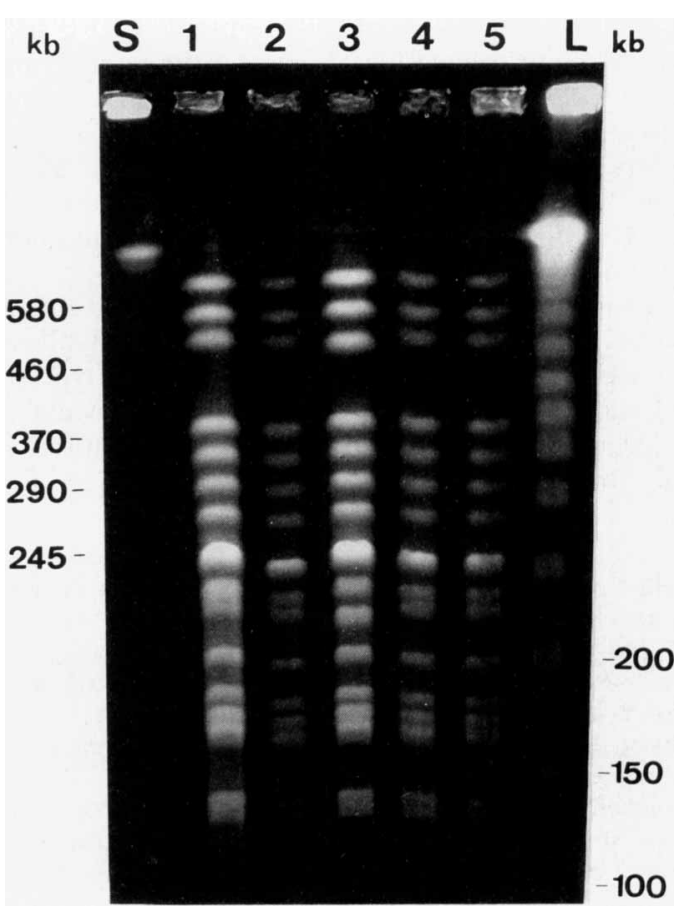

FIG. 1. PFGE of NotI restriction fragments from mammal isolates Kizilchaman, Karakabay, Kornilov, and Bernkopf (lanes 1 through 4, respectively) and strain Dadas I (lane 5). The digestion products were separated by electrophoresis at $150 \mathrm{~V}$ for $40 \mathrm{~h}$ in $1 \%$ agarose- $0.5 \times$ Tris-borate-EDTA. The pulse times were $10 \mathrm{~s}(10 \mathrm{~h}), 20 \mathrm{~s}(12 \mathrm{~h}), 50 \mathrm{~s}$ $(14 \mathrm{~h})$, and $100 \mathrm{~s}(2 \mathrm{~h})$. Lanes $\mathrm{S}$ and $\mathrm{L}$ contained size markers (Saccharomyces cerevisiae and lambda phage DNA, respectively).

group serovars (13). Consequently, strain Dadas I should be considered a member of a new serovar in serogroup Grippotyphosa.

Agglutination with a panel of 13 MAbs indicated that strain Dadas I produces a unique MAb pattern compared with the patterns obtained for the other reference serovar strains (Table 2). Very similar MAb patterns were obtained for Dadas I and isolates Kornilov, Bernkopf, Kizilchaman, and Karakabay; the single exception was one MAb 71-3, which agglutinated only strain Dadas I (data not shown).

TABLE 2. Agglutination titers obtained with 13 different MAbs for reference strains of serovars of the Grippotyphosa serogroup and strain Dadas I

\begin{tabular}{|c|c|c|c|c|c|c|c|c|c|c|c|c|c|c|}
\hline \multirow{2}{*}{ Strain } & \multirow{2}{*}{ Serovar } & \multicolumn{13}{|c|}{ Agglutination titer $\left(10^{3}\right)^{a}$} \\
\hline & & $\begin{array}{c}\text { MAb } \\
71-2\end{array}$ & $\begin{array}{c}\text { MAb } \\
71-3\end{array}$ & $\begin{array}{c}\text { MAb } \\
71-9\end{array}$ & $\begin{array}{l}\text { MAb } \\
71-13\end{array}$ & $\begin{array}{l}\text { MAb } \\
71-16\end{array}$ & $\begin{array}{l}\text { MAb } \\
71-17\end{array}$ & $\begin{array}{l}\text { MAb } \\
164-1\end{array}$ & $\begin{array}{l}\text { MAb } \\
165-1\end{array}$ & $\begin{array}{l}\text { MAb } \\
165-2\end{array}$ & $\begin{array}{l}\text { MAb } \\
165-3\end{array}$ & $\begin{array}{l}\text { MAb } \\
165-7\end{array}$ & $\begin{array}{l}\text { MAb } \\
165-8\end{array}$ & $\underset{165-12}{\mathrm{MAb}}$ \\
\hline Moskva V & grippotyphosa & 5 & 0.6 & 40 & 10 & 40 & 20 & $-^{b}$ & 10 & 1 & 10 & 5 & - & - \\
\hline RM2 & muelleri & 1 & 0.6 & 20 & 10 & 40 & 40 & - & 81 & 0.6 & 10 & 10 & - & - \\
\hline Wumalasena & ratnapura & 1 & - & 5 & 20 & 5 & 20 & - & 40 & 0.6 & 10 & 2 & 5 & 2 \\
\hline Valbuzzi & valbuzzi & 5 & 0.6 & 20 & 20 & 0.6 & 40 & - & 40 & 1 & 20 & 10 & 0.3 & 0.6 \\
\hline $\mathrm{Aa} 14$ & bananal & - & - & 1 & - & - & 5 & - & 2 & 0.1 & 2 & 0.6 & - & - \\
\hline 1880 & liangguang & - & - & 1 & - & - & 20 & - & 20 & 2 & 10 & 1 & - & - \\
\hline Kipod & vanderhoedeni & 0.6 & - & 2 & 0.08 & - & 0.6 & 20 & 0.08 & 10 & - & 1 & 0.6 & 0.3 \\
\hline CZ 188 & canalzonae & - & - & 2 & - & - & 5 & - & - & - & - & 0.1 & - & - \\
\hline M4 & huanuco & 10 & - & - & 1 & - & - & - & - & - & - & - & - & - \\
\hline Dadas I & & 0.3 & 10 & 81 & 10 & 20 & 40 & - & 20 & 1 & 20 & 2 & 10 & 5 \\
\hline
\end{tabular}

\footnotetext{
${ }^{a}$ Antibody titers are expressed by the reciprocal of the serum dilution.
}

$b-,<0.020$. 
The PFGE analysis revealed an unusual LRFP for strain Dadas I (7). Four other isolates, which originated from different regions of the world, including Russia (strain Kornilov), Israel (strain Bernkopf), and Turkey (strains Kizilchaman and Karakabay), were submitted for identification by PFGE and produced the same NotI restriction pattern as strain Dadas I (Fig. 1). This finding was corroborated by using another rarely cutting endonuclease, SgrAI (data not shown).

In addition to representing a new serovar, strain Dadas I represents a new LRFP in serogroup Grippotyphosa. The name dadas is proposed for the new serovar; the type strain of this serovar is strain Dadas I, and this strain is available from the collections of leptospirosis reference laboratories in Amsterdam, Bratislava, and Paris.

\section{REFERENCES}

1. Baril, C., C. Richaud, G. Baranton, and I. Saint Girons. 1989. Linear chromosome of Borrelia burgdorferi. Res. Microbiol. 140: 507-516.

2. Canale-Parola, E. 1977. Physiology and evolution of spirochetes. Bacteriol. Rev. 41:181-204.

3. Dikken, H., and E. Kmety. 1978. Serological typing methods of leptospires. Methods Microbiol. 11:259-307.

4. Ellinghausen, H. C., and W. G. McCullough. 1965. Nutrition of Leptospira pomona and growth of the 13 other serotypes: fractionation of oleic albumin complex and a medium of bovine albumin and polysorbate 80. Am. J. Vet. Res. 26:45-51.

5. Faine, S. 1987. Guidelines for the control of leptospirosis. World Health Organization, Geneva.

6. Herrmann, J. L., C. Baril, E. Bellenger, P. Perolat, G. Baranton, and I. Saint Girons. 1991. Genome conservation in isolates of Leptospira interrogans. J. Bacteriol. 173:7582-7588.

7. Herrmann, J. L., E. Bellenger, P. Perolat, G. Baranton, and I. Saint Girons. 1992. Pulsed-field gel electrophoresis of Not I digests of leptospiral DNA: a new rapid method of serovar identification. J. Clin. Microbiol. 30:1696-1702.

8. Hovind-Hougen, K. 1979. Leptospiraceae, a new family to include Leptospira noguchi 1917 and Leptonema gen. nov. Int. J. Syst. Bacteriol. 29:245-251.

9. Inada, R., Y. Ido, R. Hoki, M. Kaneko, and H. Ito. 1916. The etiology, mode of infection, and specific therapy of Weil's disease (Spirochaetosis icterohaemorrhagica). J. Exp. Med. 23:377-402.
10. Johnson, R. C., and S. Faine. 1984. Family II. Leptospiraceae, p. 62-67. In N. R. Krieg and J. G. Holt (ed.), Bergey's manual of systematic bacteriology, vol. 1. Williams and Wilkins, Baltimore.

11. Johnson, R. C., and V. G. Harris. 1967. Differentiation of pathogenic and saprophytic leptospires. I. Growth at low temperatures. J. Bacteriol. 94:27-31.

12. Kmety, E. 1957. Proposal for a standard method of the agglutination-lysis reaction in leptospirosis. Cesk. Epidem. Mikrob. Immun. 6:372-377.

13. Kmety, E., and H. Dikken. 1988. Revised list of Leptospira serovars. University Press, Groningen, The Netherlands.

14. Korver, H., W. A. Ellis, M. J. Kim, and W. J. Tepstra. 1991. Antigenic and genetic analysis of Korean Leptospira isolates, p. 235-270. In Y. Koyabashi (ed.), Leptospirosis. Proceedings of the Leptospirosis Research Conference 1990. University of Tokyo Press, Tokyo.

15. Koyabashi, Y., T. Tamai, T. Oyama, H. Hasegawa, E. Sada, T. Kusaba, and M. Hamaji. 1984. Characterization of monoclonal antibodies against etiological agents of Weil's disease. Microbiol. Immunol. 28:359-370.

16. Martin, L., and A. Pettit. 1918. Sero-diagnostic de la spirochétose ictérohémorragique. Bull. Mem. Soc. Hop. Paris 42:672-675.

17. Pillot, J., and A. Ryter. 1965. Structure des spirochètes. I. Etude des germes Treponema, Borrelia et Leptospira au microscope électronique. Ann. Inst. Pasteur (Paris) 108:791-804.

18. Ramadass, P., B. D. W. Jarvis, R. J. Corner, D. Penny, and R. B. Marshall. 1992. Genetic characterization of pathogenic Leptospira species by DNA hybridization. Int. J. Syst. Bacteriol. 42:215-219.

19. Terpstra, W. J., H. Korver, J. V. Leeuwen, P. R. Klaster, and A. H. J. Kolk. 1985. The classification of Sejroe group serovars of Leptospira interrogans with monoclonal antibodies. Zentralbl. Bakteriol. Parasitenkd. Infektionskr. Hyg. Abt. 1 Orig. Reihe A 259:498-506

20. Weil, A. 1886. Ueber eine eigenthümliche mit Milztumor, Icterus und Nephritis einhergehende acute Infectionskrankheit. Dtsch. Arch. Klin. Med. 39:209.

21. Woese, C. R. 1987. Bacterial evolution. Microbiol. Rev. 51:221271.

22. Yasuda, P. H., A. G. Steigerwalt, K. R. Sulzer, A. F. Kaufman, F. Rogers, and D. J. Brenner. 1987. Deoxyribonucleic acid relatedness between serogroups and serovars in the family Leptospiraceae, with proposals for seven new Leptospira species. Int. J. Syst. Bacteriol. 37:407-415. 